\title{
Traditionally used wild edible greens in the Aegean Region of Turkey
}

\author{
Yunus Dogan* \\ Buca Faculty of Education, Dokuz Eylul University, 35150 Buca-Izmir, Turkey
}

\section{Abstract}

Turkey has the largest coastal area in the Mediterranean, possesses an extraordinarily rich flora, and a great traditional knowledge. This diversity of plants naturally affects the traditional use of plants and is reflected in the rich Turkish cuisine. Consequently, the Mediterranean Diet (whose typical components are wild greens) constitutes one of the important elements of Turkish cuisine. For this reason, the aim of this study was to determine the consumption of wild edible green plants for the Aegean Region of Turkey and to establish the similarities to or differences from consumption in other regions and other cuisine in the Mediterranean Basin. This study compiles and evaluates the ethnobotanical data currently available. There were 111 taxa that were identified as wild edible greens in the study area belonging to 26 different families. Asteraceae (21 taxa) were the most commonly consumed as food. It was followed by Boraginaceae with 19 taxa, Apiaceae with 15 taxa and Lamiaceae with 7 taxa, respectively. Rumex and Erodium were the most represented genera with 4 species. Tamus communis and Asparagus acutifolius, Mediterranean elements and distributed in all of the Mediterranean Basin, are among the most widely consumed wild plants in the area. Wild edible plants are consumed in a variety of ways. The most common type of consumption (79 taxa) was in salads. The fact that the majority of the plants used in the area are consumed in salads shows the close relationship between the local diet and the concept of the Mediterranean Diet. As a result, very promisingly, there is a renewed or increasing interest in consuming wild food plants as part of this diet.

Keywords: wild edible greens, ethnobotany, traditional knowledge, consumption, Mediterranean Diet, Aegean, Turkey

\section{Introduction}

The type of food consumed reflects the identity of people and the use of wild food plants is a very good indicator of traditional local knowledge. The main characteristics of the Mediterranean Diet has been described as mainly composed of vegetables, salads, fruits and spices, whole-grain cereals, pasta, nuts, legumes, olive oil, seafood, a moderate consumption of wine with meals, poultry consumed in low-to-moderate amounts, and a relatively low consumption of red meat [1-3]. By supplying micronutrients, vitamins, and minerals, wild plants play an important role in complementing staple foods [4]. Many of these wild foods are common and productive, as well as being highly nutritious, palatable, and easily harvested [5]. They are also important as a source of income for poor communities, as well as being a source of food and considered a healthy diet by many. Diets consumed by Mediterranean peoples have been a subject of interest since antiquity, with

\footnotetext{
*Email: yunus.dogan@deu.edu.tr

This is an Open Access digital version of the article distributed under the terms of the Creative Commons Attribution 3.0 License (creativecommons.org/licenses/by/3.0/), which permits redistribution, commercial and non-commercial, provided that the article is properly cited.
}

more recent investigations focused on their evident health benefits.

However, the Mediterranean Basin contains many different cultures, religious beliefs, and ecologic backgrounds. This has resulted in many diets, sharing a multitude of elements. But at the same time, these diets differ in distinct local or regional traditions. Food and medicinal uses have always been the most relevant reasons for plant management in the folk traditions of the Mediterranean Region, and they still continue to be so, even in cultures that are progressively losing their close relationship with nature [2].

The studies show that Mediterranean Diet contains important dietary components that may contribute to a lower risk of cancer. Several micro-components with antioxidant potential are underlying factors that define the health benefits of this type of diet. The relative longevity of the Mediterranean people is attributed to the type of diet they consume [6]. The Mediterranean Diet is an example of sustainable food production. It is a dietary pattern that can combine taste and health, environmental protection, biodiversity protection, and consumption of local and seasonal products [7].

Turkey, which has the largest coastal area in the Mediterranean, possesses an extraordinarily rich flora and a great traditional knowledge. Due to its climate and geographical position, Turkey, with its 10000 taxa, is one of the richest countries in Europe and the Middle East, in terms of flora [8]. A total of $1 / 3$ of the plant taxa of Turkey is endemic [9]. Anatolian people have been profiting from this variety and using plants as food and medicine since the Paleolithic [10]. This 
diversity of plants naturally affects the traditional use of plants and is reflected in the rich Turkish cousine. Consequently, the Mediterranean Diet constitutes one of the important elements of Turkish cuisine.

Despite all the great qualities of the Mediterranean Diet, in many Mediterranean regions, including Turkey, the traditions regarding the diet are under the risk of disappearing, and therefore there is an urgent need to study them [11]. In this modern era where the fast-food culture is spreading worldwide and the transfer of ethnobotanical knowledge from old generations is diminishing, this study will be helpful for both recording the information regarding the consumption of wild edible plants as a food source and providing people with new ideas. For this reason, the aim of present study was to review the consumption of wild edible green plants and establish the similarities to or differences from consumption in other regions and other cuisine in the Mediterranean Basin.

Several previous studies have described the traditional knowledge about the plants in the research area and the uses and different needs for them such as everyday household items, traditional crafts, etc. $[8,12-17]$.

\section{General characteristics of the study area}

CLIMATE. The Mediterranean climate is dominant in the study area, particularly along the shores of the Mediterranean, Aegean, and Marmara regions. In the Mediterranean climate, summers are hot and dry; winters are mild and rainy. The maximum precipitation falls in the winter; the minimum falls in summer. A long and arid period predominates from mid-May till mid-October. In April and May, clear and still weather conditions alternate with rain showers and cold. The difference between summer and winter precipitation is very high. The average annual precipitation is 600 to $1000 \mathrm{~mm}$. The annual average temperature is 18 to $20^{\circ} \mathrm{C}$. Mountains in the Aegean Region lie perpendicular to the shore and this allows the Mediterranean climate to reach inland [18-20].

VEGETATION. The study area includes the Aegean Region of Turkey (Fig. 1). It is geographically situated in the western part of Turkey. Markgraf [21] has divided the Mediterranean Region into two subdivisions: the west and the east provinces. According to this division, the study area lies in the East Mediterranean Province. In the Mediterranean Basin there is huge topographic, climatic, and geographic variability giving rise to an astounding array of species and habitat diversity [22].

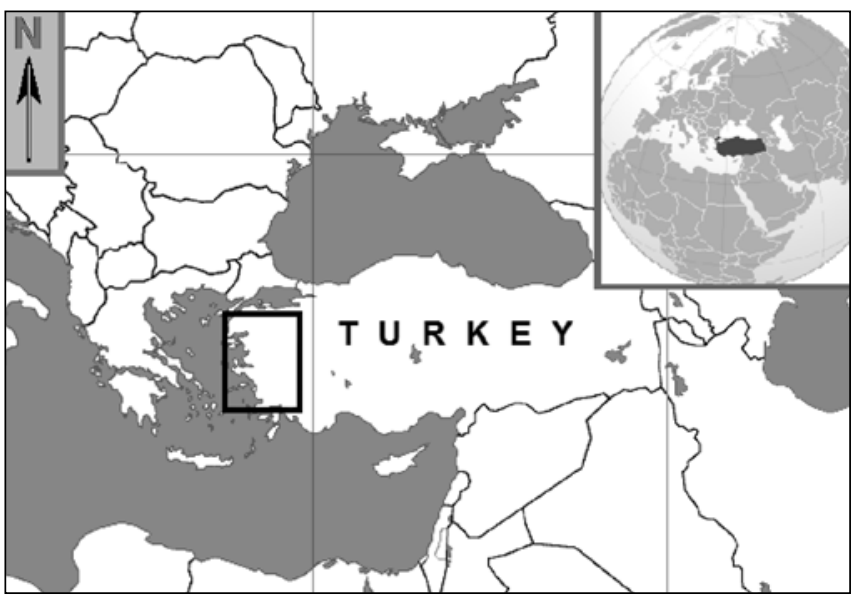

Fig. 1 The map of the study area.
The vegetation in general consists of sclerophyllous shrubs and trees. The typical Mediterranean species are Styrax officinalis L., Rhamnus palaestinus Boiss., Rhamnus punctatus Boiss., Arbutus andrachne L., Cistus creticus L., Satureja thymbra L., Salvia triloba L., and Sarcopoterium spinosum (L.) Spach. Some of the representative species found in both the east and west provinces are Quercus ilex L., Quercus coccifera L., and Pistacia terebinthus L. The East Mediterranean Province exhibits a strong influence from the Irano-Turanian region. The typical dominant species in the Mediterranean Region is Quercus ilex. This species is replaced in the East Mediterranean Province by Quercus coccifera and among the tree species are Ceratonia siliqua L., Olea europaea L. subsp. oleaster (Hoffmanns. \& Link) Negodi, and Pistacia lentiscus L. The maquis was formed as a result of the destruction of tree formations. They develop on the slopes which lack soil cover deep enough to support forest vegetation and consist of the sclerophyllous species of shrubs, together with some climbers like Lonicera, Clematis, and Asparagus.

The borders of the Mediterranean Region in Turkey were drawn by Zohary [23]. They correspond with the southern border of the distribution of Pinus brutia Ten. The latter is an indicator of the true Mediterranean conditions. In some places this border is drawn by the Quercus ithaburensis Decne. subsp. macrolepis (Kotschy) Hedge, but never by plants like Quercus cerris, Pinus nigra Arn., and Juniperus spp. Black pine is a typical indicator of the oro- and sub-Mediterranean vegetation. This vegetation is phytogeographically closer to euxinian vegetation than the Mediterranean one. The region close to Central Anatolia serves as a transition zone between the Mediterranean, the semi-desert belt, and the steppes. The climate and vegetation in general show the same characteristics as those of the Mediterranean [24].

\section{Material and methods}

This study compiles and evaluates the ethnobotanical data currently available. More than seventy literature sources were reviewed [25-101] including six from the study area [25-30]. Plant names are given according to Davis [31]. A literature review was carried out firstly for the Aegean Region, which is target study area, and then for all of Turkey and the wild edible green plants used in these areas were identified. According to Turner et al. [5], edible wild plants are root vegetables, edible greens, fleshy fruits, grains, seeds, and nuts. This study focused on the wild edible greens. It includes leaves, stems, and shoots. In addition, based on field observations, the consumption of some plant taxa is reported here for the first time. The plants' scientific names, families, local and English names, parts consumed, type of consumption and related sources are also given in Tab. 1.

\section{Results and discussion}

Altogether, 111 taxa of wild edible greens have been used in the study area (Tab. 1). Rumex and Erodium are the most represented genera, with four species. Amaranthus, Tragopogon, and Papaver were represented by three species. Allium, Anchusa, Chenopodium, Chrysanthemum, Eryngium, Lamium, Lepidium, Scorzonera, Silene, Sinapis, Sisymbrium, Smyrnium, Sonchus, and Urtica were represented by two species (Fig. 2). 


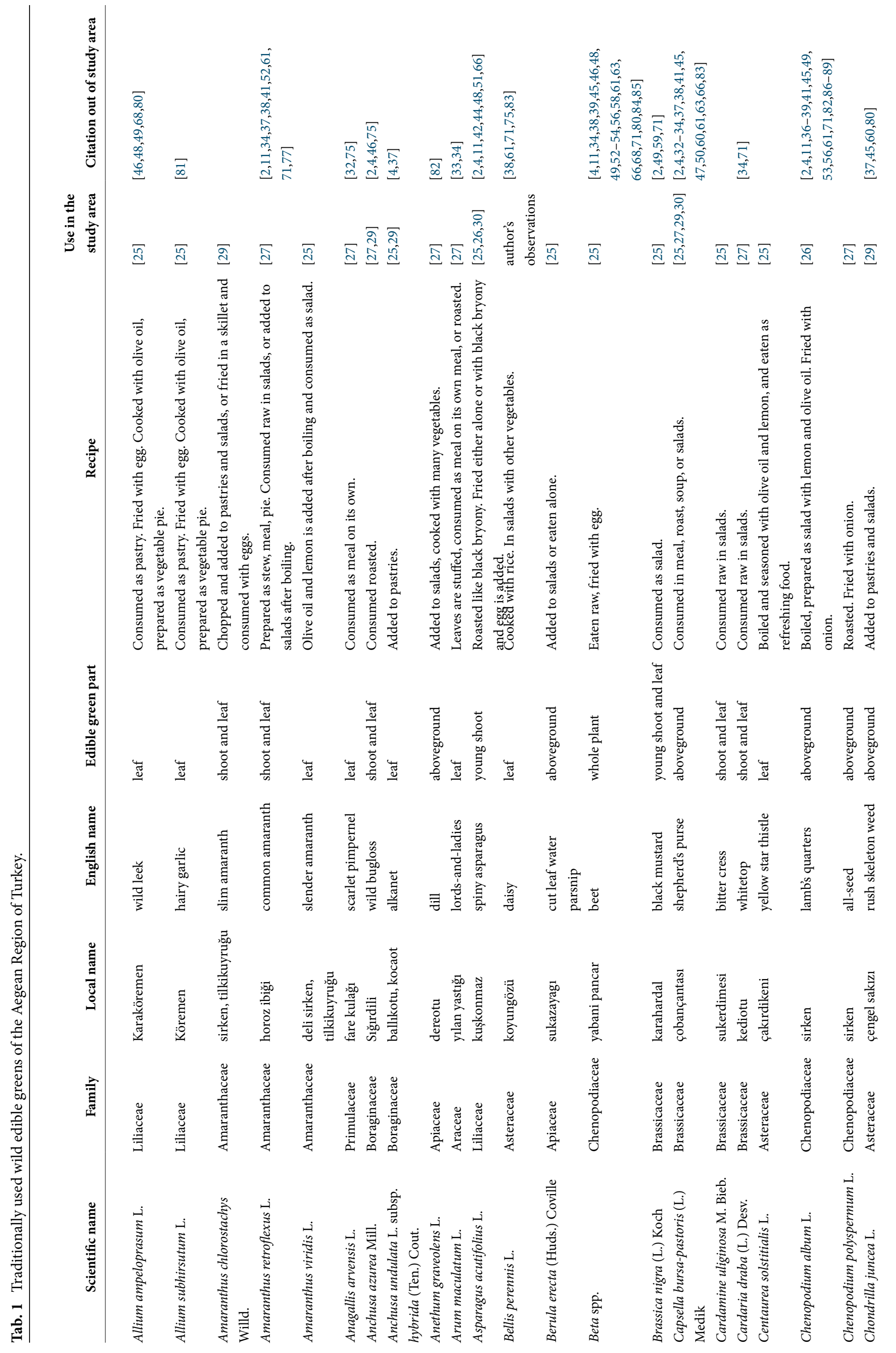




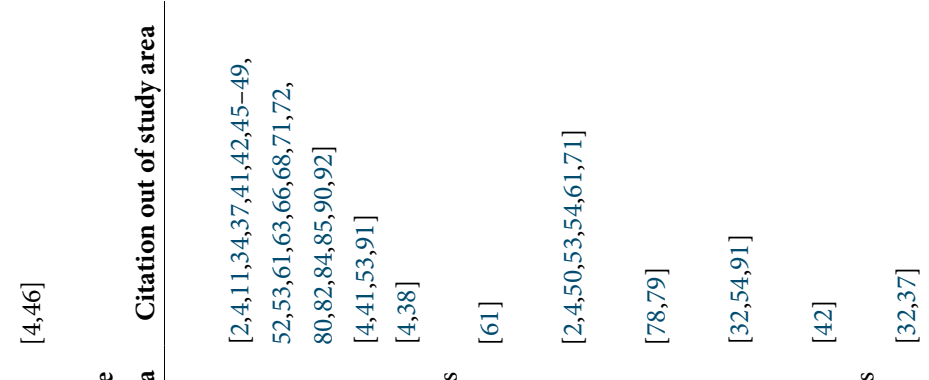

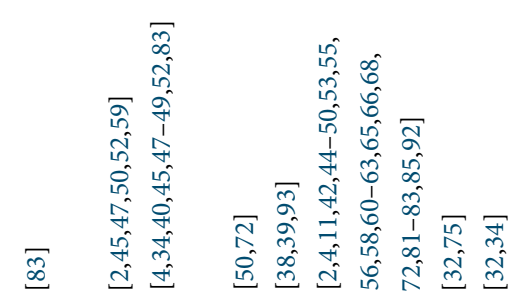

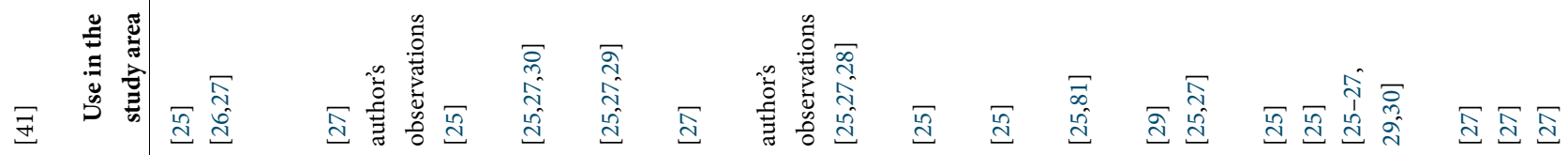

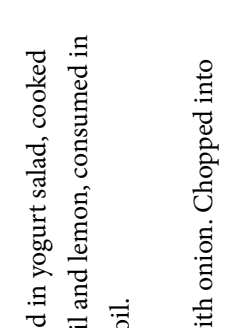

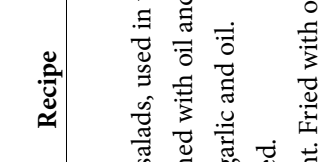

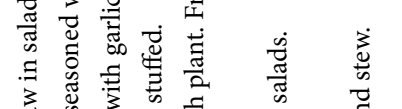

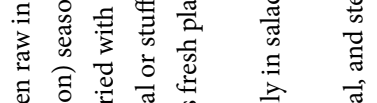

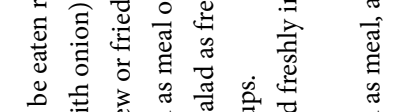

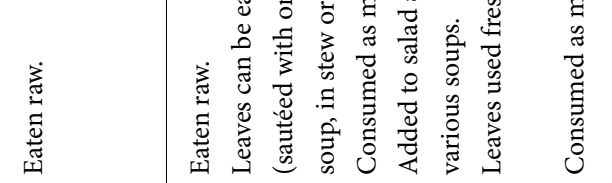

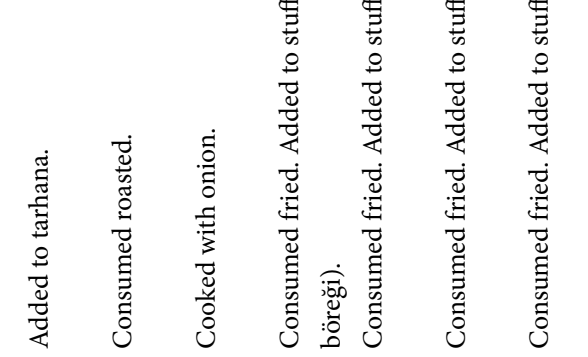

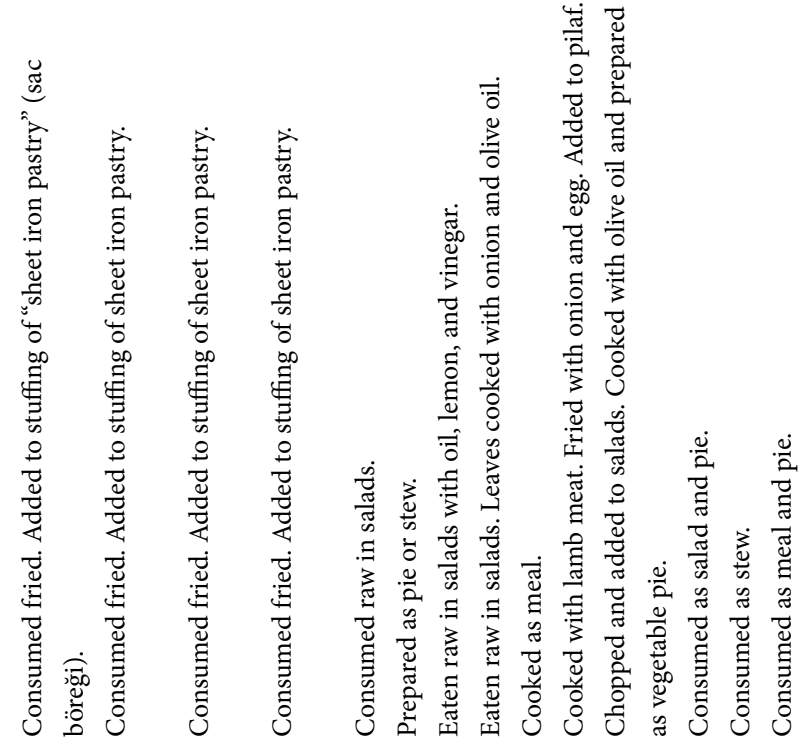

(

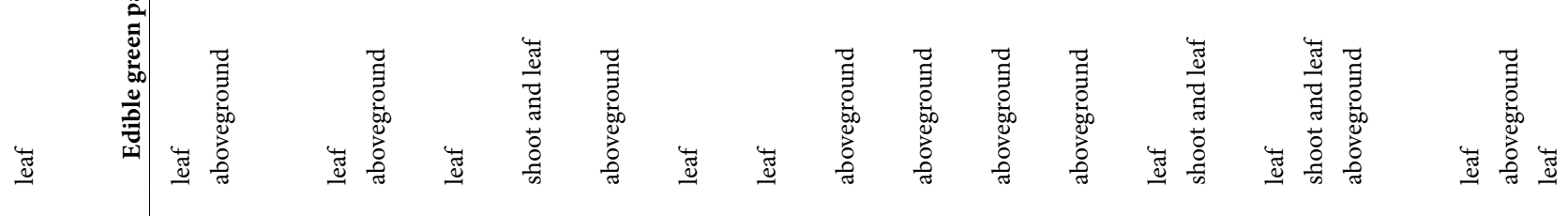

In

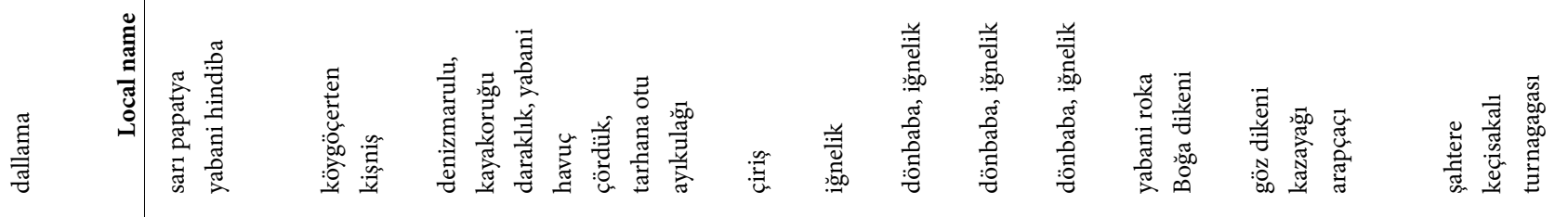

In

(1) 


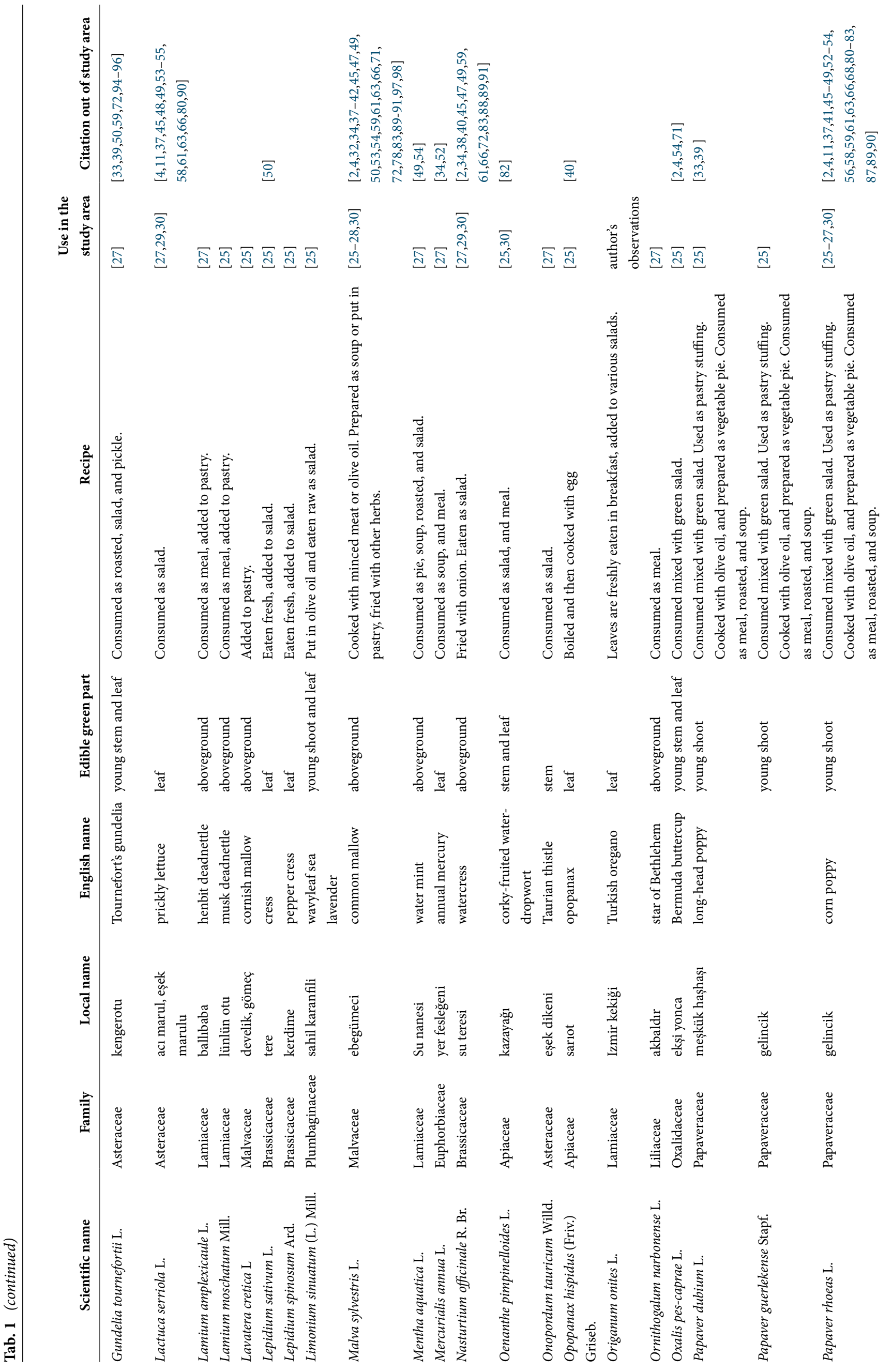




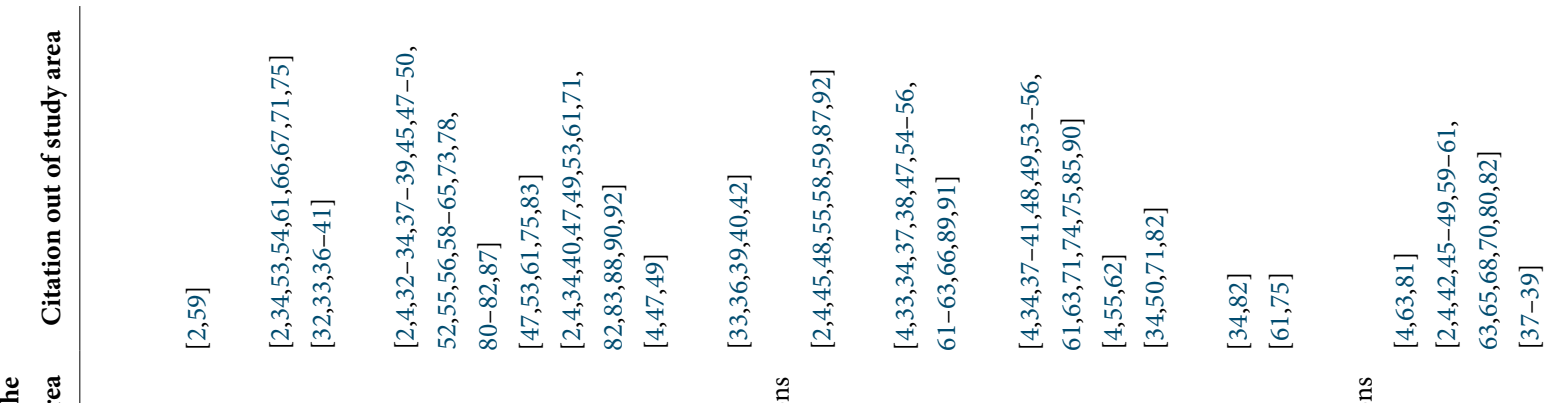

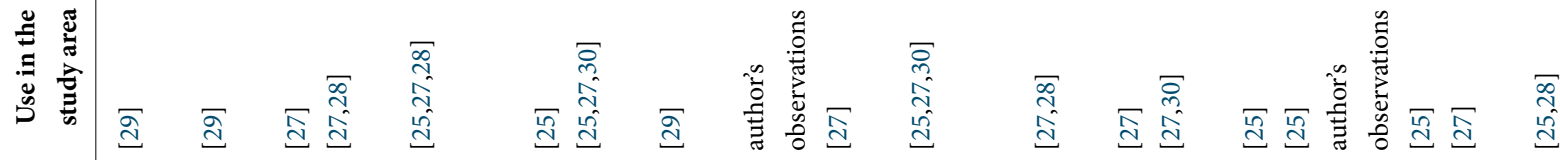

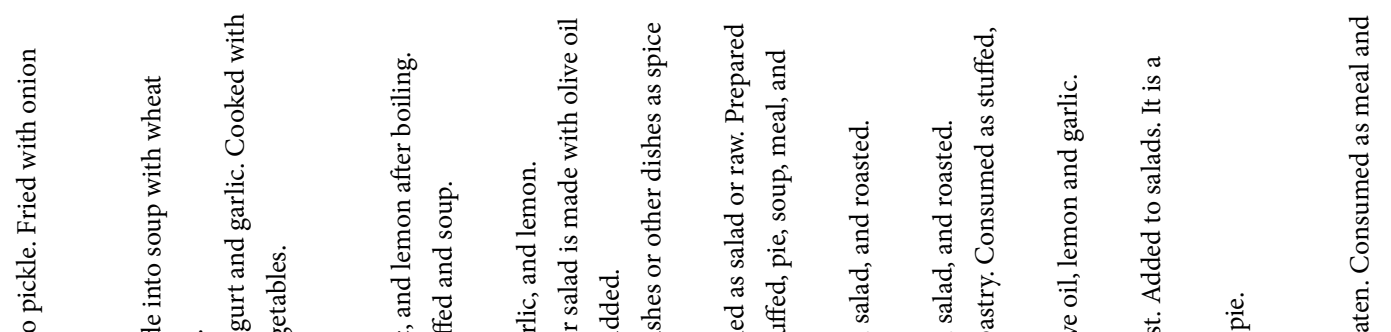

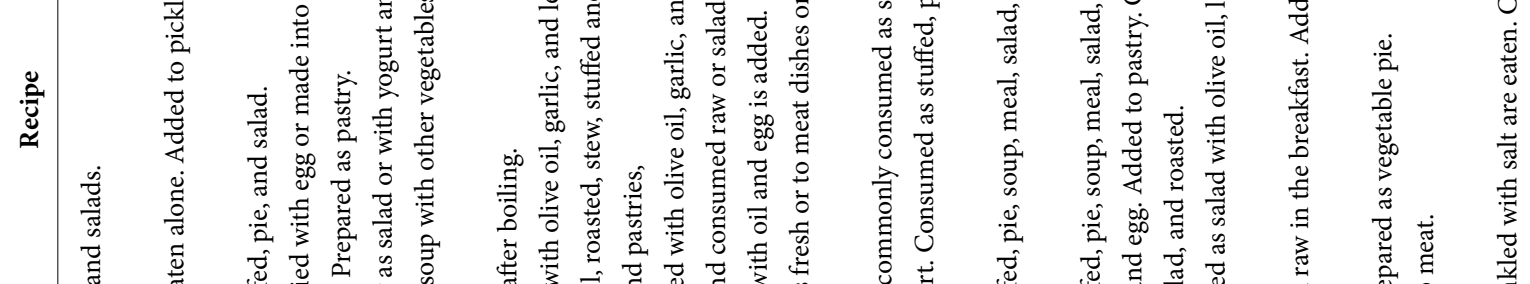

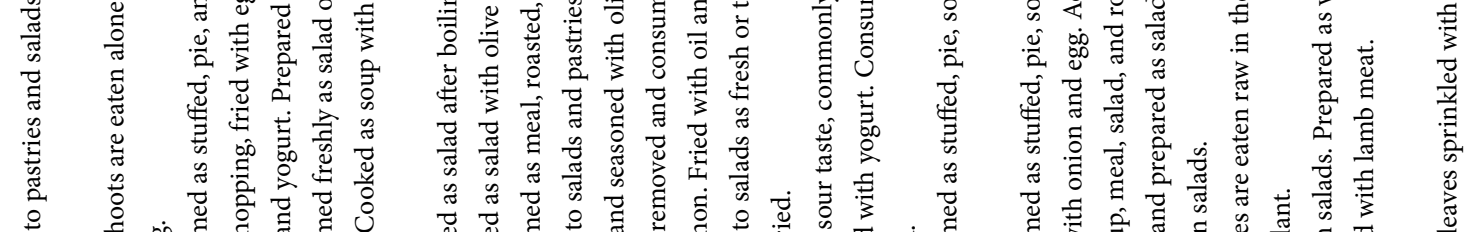

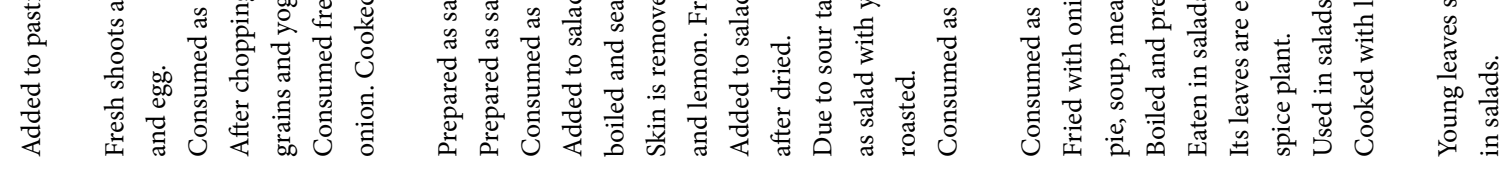

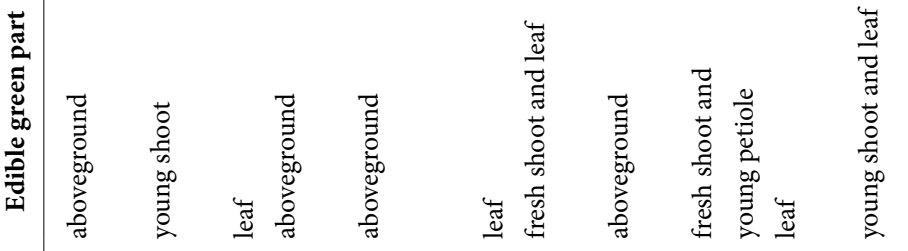

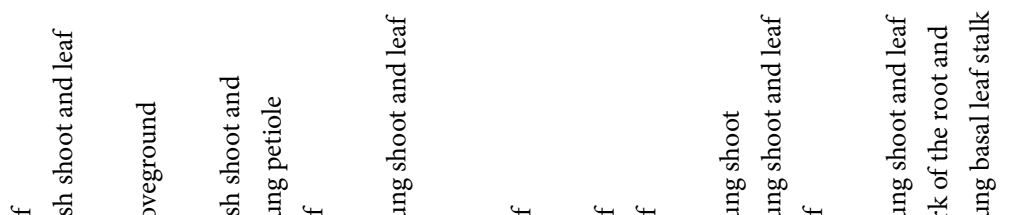

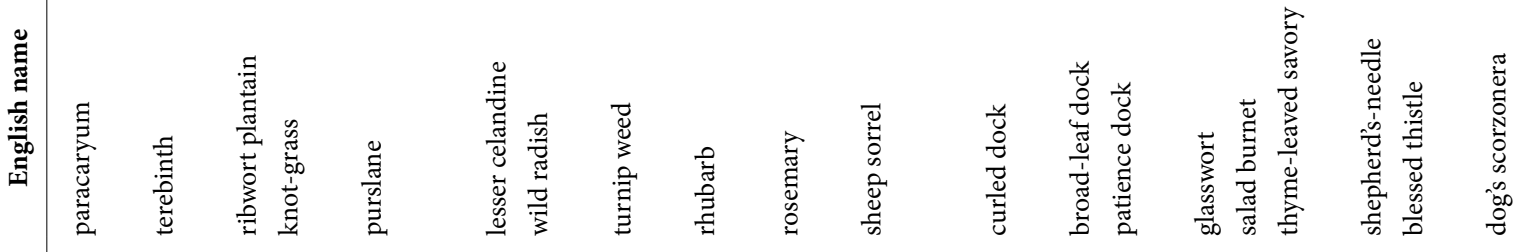

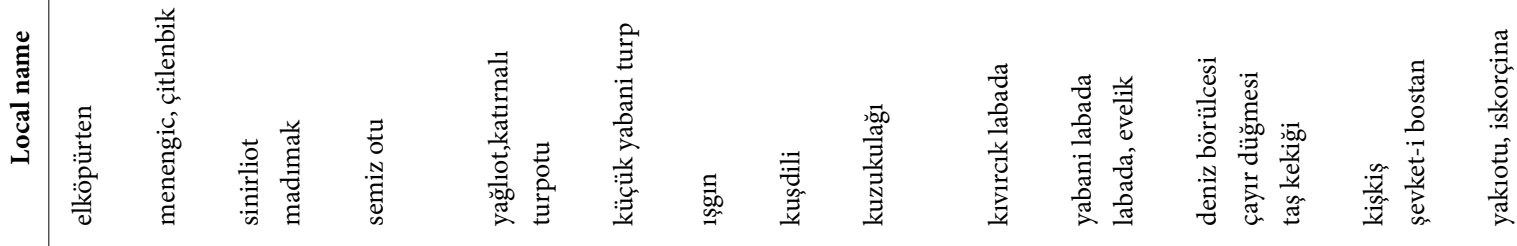

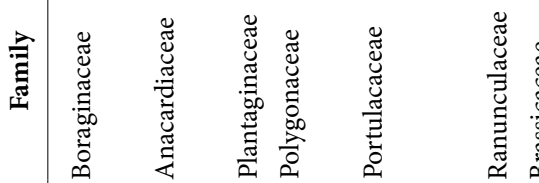

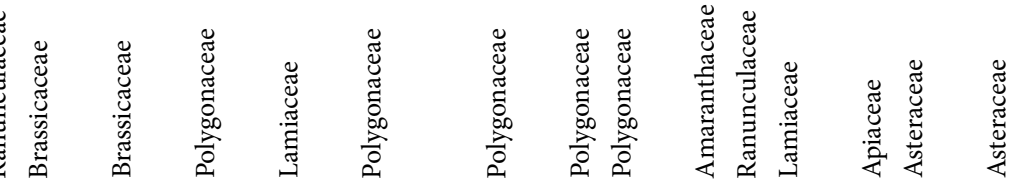

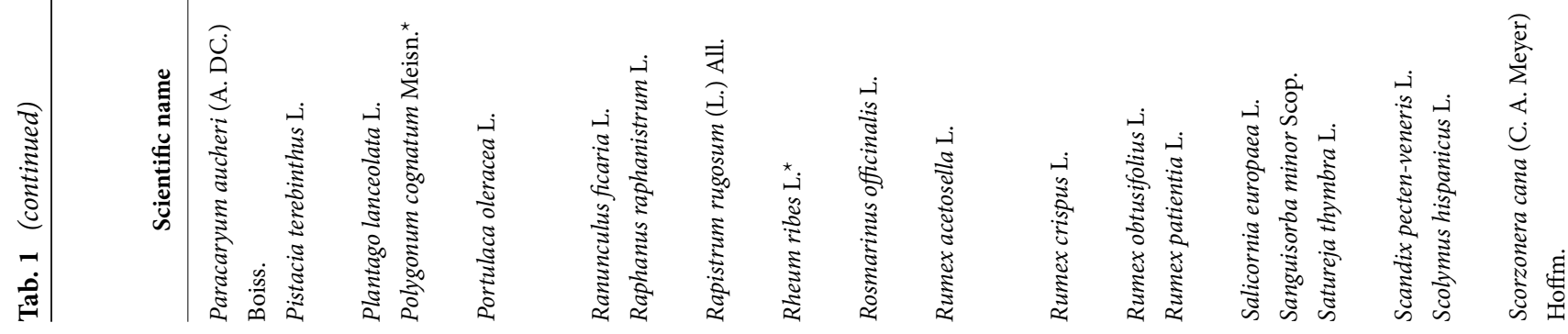




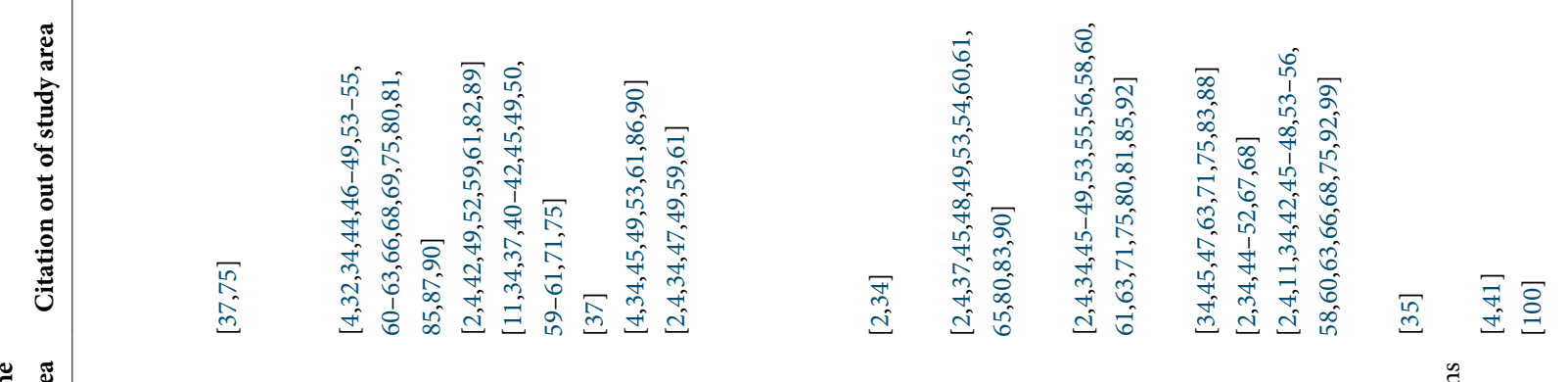

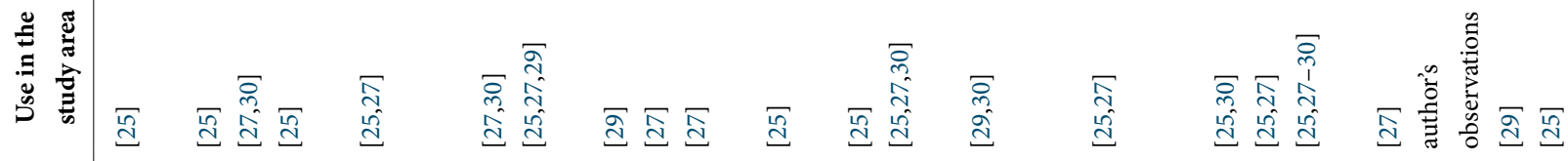

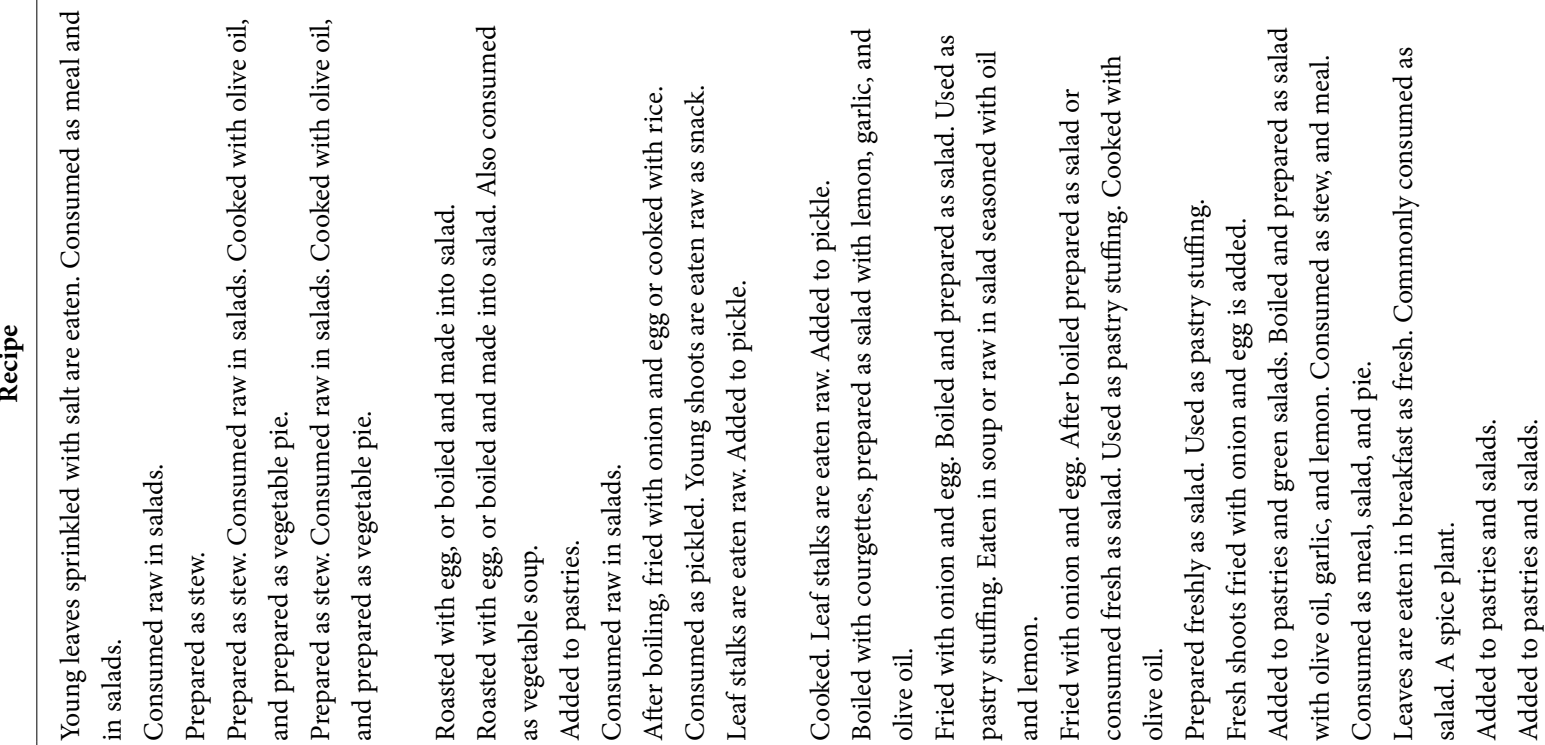

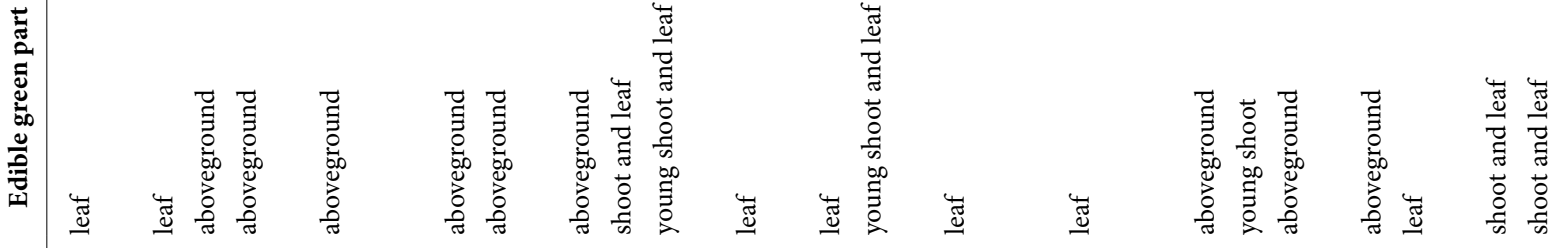

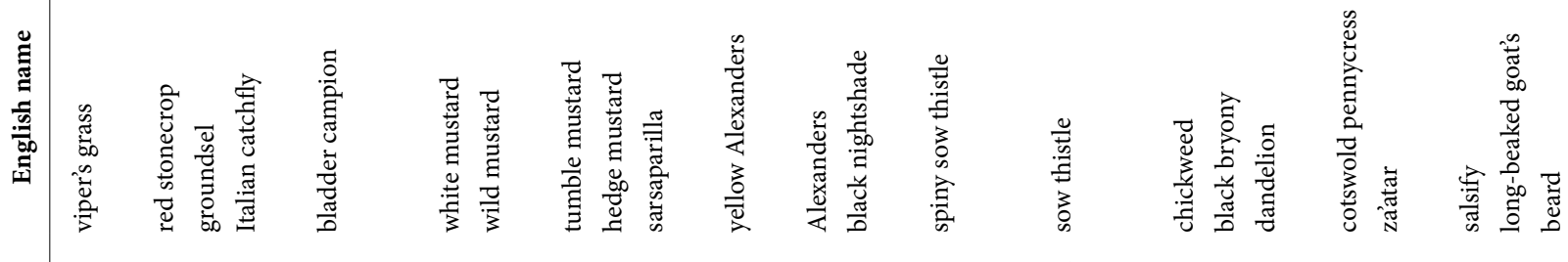

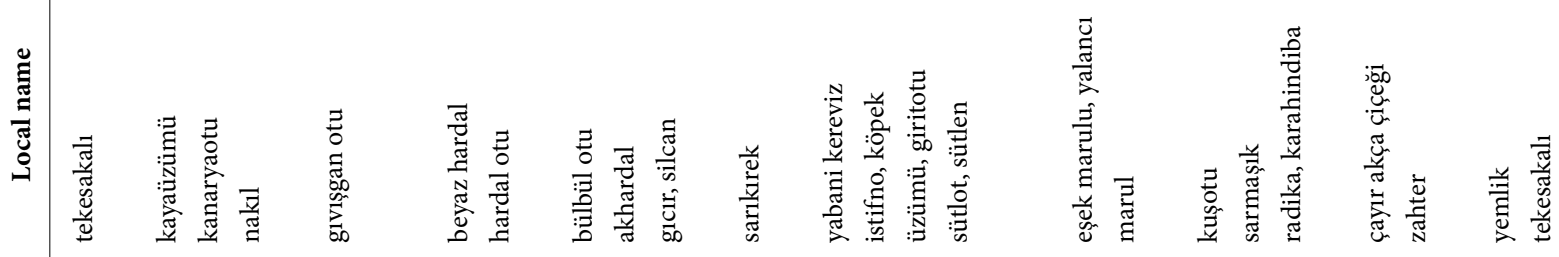

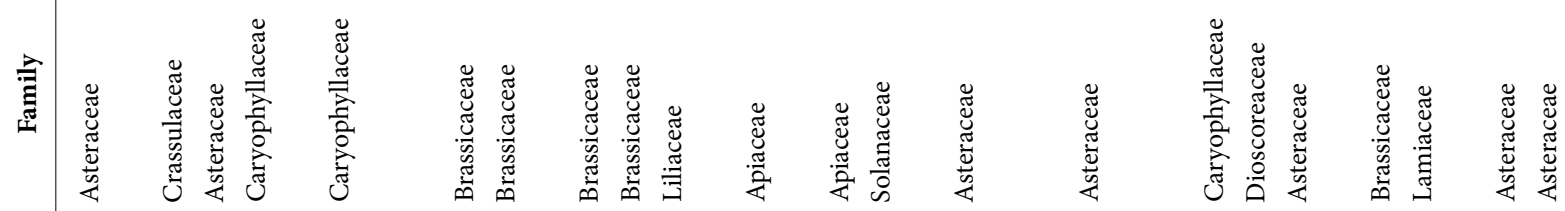
|| 


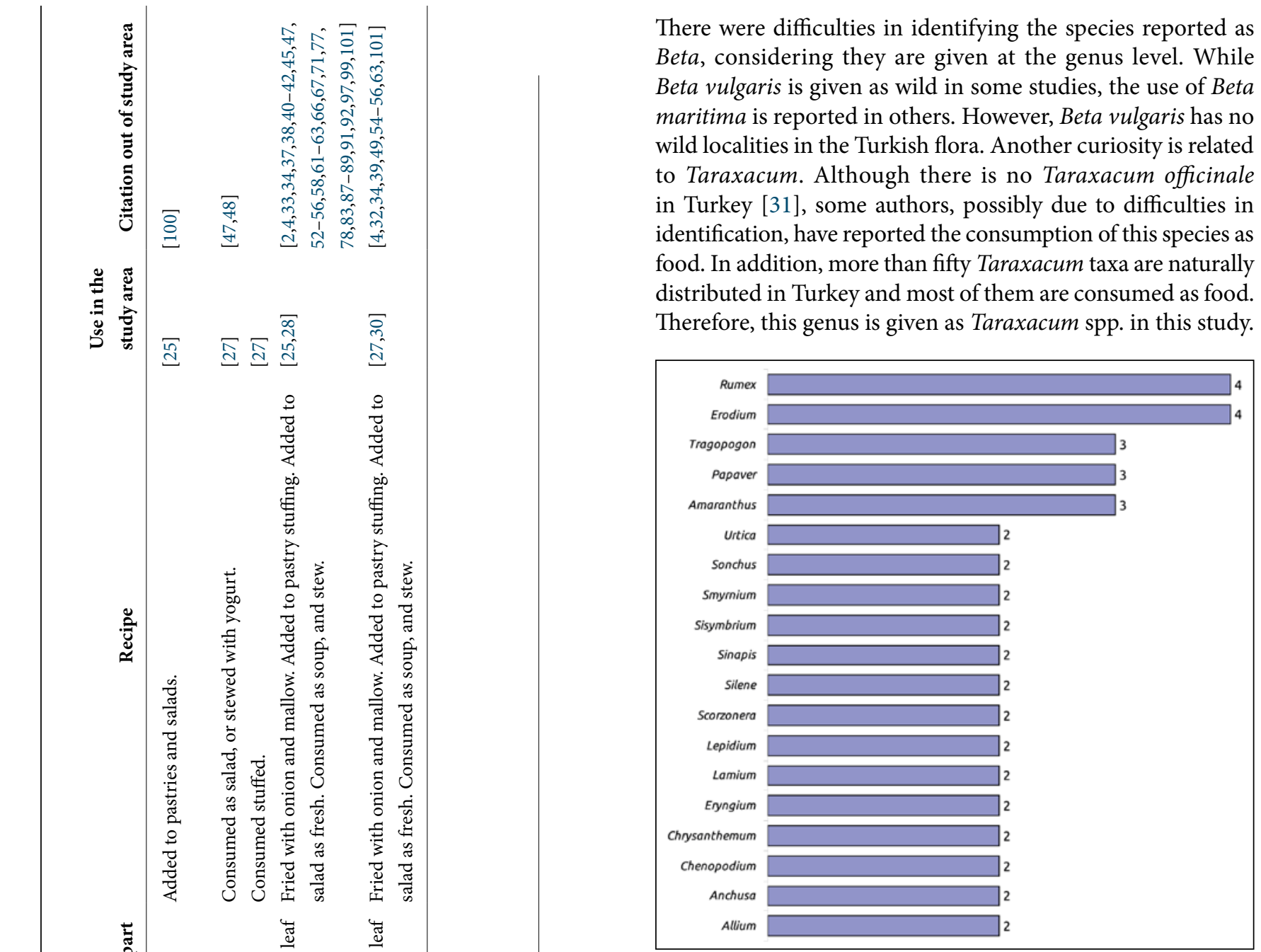

Fig. 2 Plant genera with the highest number of taxa in the study area.

Wild edible green vegetables identified in this study belong to 26 different families. Asteraceae are best represented (21 different taxa, $18 \%$ of the wild green vegetables). Other well represented families are Boraginaceae with 19 taxa, Apiaceae with 15 taxa, and Lamiaceae with 7 taxa, respectively (Fig. 3). The other 22 families have less representation, between one to six taxa each.

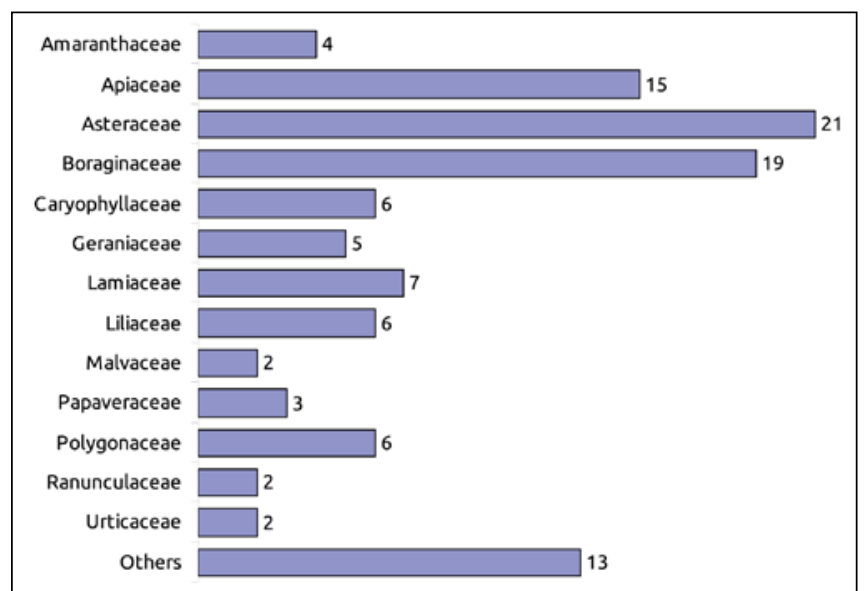

Fig. 3 Plant families with the highest number of taxa in the study area. 
Wild edible plants are consumed in a variety of ways. The identified consumption types are divided into nine main categories: green salad (fresh plants and dressing), salad after boiling, salad with yogurt, raw/fresh, main dish (sautéed with oil and onion, also may have different vegatables, rice, meat etc. added), pastry/pie, soup, pickle, and stuffed. However, it must be noted that many species could be classified in more than one category. The most common type of consumption is as a salad (Fig. 4) with three sub-categories under this consumption type: green salad, salad after boiling, and salad with yogurt. Among them, only salad with yogurt is consumed without oil. All other salad types (76 taxa) are prepared with oil, as it is a typical Mediterranean region. Because olive oil is readily available in the region, it is preferred in all salads and most foods. In addition to olive oil, vinegar, lemon, and garlic are also added to salads, depending on the type of the salad. It has already been reported that salad and vegetable dishes prepared as traditional recipes in Turkish cuisine make use of many local wild plants $[10,32]$. Another category, following the consumption as salads, is the main dish category with 71 taxa. The pastry/pie category is represented by 42 taxa. The consumption habits of the Turkish people play an important role in the high number for this category. Due to the partiality for food made with dough, various tastes are obtained by mixing many plants in pastries. Twenty-two taxa are consumed as soup. Another category of consumption is stuffed foods. In this study area, stuffed rolls (so called "sarma" rolls) is a popular dish made especially with rice, but sometimes cracked wheat (bulgur) is preferred. Sarma rolls are primarily wrapped with the leaves of the grapevine (Vitis vinifera L.) and then those of cabbage (Brassica oleracea L.). However, nine other taxa are used to wrap sarma as well. Among these, Arum maculatum, which is a poisonous plant, so the leaves of this plant is consumed as sarma only after being boiled [27,33]. This type of consumption has not been reported outside the study area, while Redžić [34] reported consumption of ground parts of this plant as mush (from Bosnia-Herzegovina).

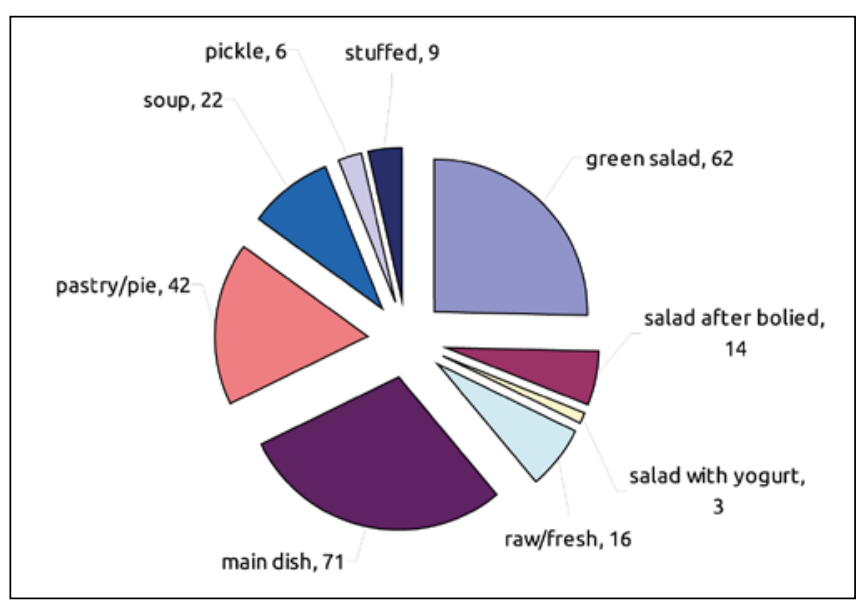

Fig. 4 Ways of consumption for the wild edible green plants in the study area.

Out of the listed wild greens some of them are both collected from the wild as well as cultivated. Plants such as Daucus carota, Eruca sativa, Allium ampeloprasum, Beta vulgaris, Foeniculum vulgare, Coriandrum sativum, Lepidium sativum, and Portulaca oleracea are mostly sold as crops. However, wild plants are either collected from nature and consumed or sold in the open markets, as well. Especially wild Eruca sativa and Lepidium sativum are commonly consumed as a salad or raw.

The consumption of plants in an area especially that of wild edible plants as food, is closely associated with the sociocultural features of the population. Particularly, the increase in ethnic variety in the area is supportive of a variety of plant usage and occurrence of more recipes. In light of this, Izmir province in the study area, with a population of over 3 million and the 3rd most populated city in Turkey, in the past hosted immigration from many areas. This fact has naturally influenced the consumption of a variety of wild edible plants. For instance, Cretan immigrants have had a great impact in this regard. In this study, it was concluded that the information regarding the consumption and recipes of plants such as Scolymus hispanicus, Solanum nigrum, and Taraxacum spp. may have been transferred to the area by immigrants from Crete.

It must be noted that the species whose flowering tops or green parts are collected in small amounts for seasoning are not included in the study (e.g. Thymbra spicata, Satureja thymbra, Origanum onites, Laurus nobilis L., Capparis ovata Desf., and Capparis spinosa L.). T. spicata (za'atar), O. onites (oregano), and S. thymbra (thyme-leaved savory) are sold as wild in many open markets of Izmir. They are dried and used as a spice, while very rarely consumed fresh. Fresh leaves of $O$. onites are consumed raw even for breakfast in and around Izmir-Beydag. Similarly, S. thymbra and T. spicata are consumed raw or added to salads. "Za'atar salad", a type of salad mostly known and consumed in Eastern and Southeastern Anatolia, is not commonly consumed in the study area [35]. Green, unripe fruits of Amygdalus communis L. are consumed very commonly in the spring months in the study area. They were not included here due to the fact that technically they are not "green vegetables". Both cultivated and wild forms are collected and sold. However, the fruit dries and hardens in a very short time and its seeds are consumed as a snack or added to food or desserts for taste.

Rheum ribes and Eremurus spectabilis do not occur in the study area and Polygonum cognatum is very rare. However, they are common in Middle and Eastern Anatolia. P. cognatum is commonly consumed in various parts of Turkey [27,28,32,33,36-41], as well as Rheum ribes [33,36,39,40,42]. It was observed that these plants are only sold in Izmir (in the study area). There is only one reference to the consumption of E. spectabilis [42] in Turkey and no references from outside the country. This could be explained by the fact that these plants are Irano-Turanian elements and therefore are not distributed in the Mediterranean Basin. Market surveys showed, that sellers collect the plants in various parts of Middle and Eastern Anatolia and then transport and sell them in the markets of Izmir, but the indigenous population never consumes these plants. They are mostly consumed by immigrants from Middle and Eastern Anatolia or people who spent their childhood there. These people also bring their unique ways of using the plants and food culture. This is one of the factors that increase the variety of dishes in the region. Similarly, salad made with Thymbra spicata, an Irano-Turanian element, is commonly consumed in Eastern and Southeastern Anatolia. Also Scorzonera elata and S. cana, though are not commonly consumed in the study area, are sold in small amounts in some markets, beacuse they are eaten by immigrants from Middle and Eastern Anatolia. Although the two species are used in some parts of Turkey $[25,28,37,39]$, there are no reports of their use in other parts of the Mediterreanean. Also, there is no report for the use 
of Origanum onites and Satureja thymbra outside of the study area. The usage of these plants is being reported for the first time based on our field observations.

Tamus communis and Asparagus acutifolius, Mediterranean elements distributed in all of the Mediterranean Basin, are among the most widely consumed wild plants in the area. An interesting fact is that one of the toxic plants identified in the study is black bryony (T. communis) $[43,44]$. The plant has a bitter taste because of its saponin content. Young shoots with leaves are the least toxic parts of the plant. They have been traditionally consumed after cooking, which destroys the toxic principles [44].

Although T. communis and A. acutifolus are among the most commonly consumed species throughout the study area, usually young shoots are fried with onion [25,27] and egg $[25,26,42]$, they are not consumed in other, non-Mediterranean, parts of Turkey. On the other hand the two species are widely used in other parts of the Mediterranean, e.g. Spain, Italy, Slovenia, Croatia, Crete, Sardinia, and Sicily, where their tender leaves are eaten both cooked and raw, in soups, and omelets [4,11,44-66]. Pieroni et al. [45] and Menendez-Baceta et al. [67] have reported that T. communis is first boiled and then cooked with egg or in other ways. It is thought that the cooking method aims to eliminate the bitter taste coming from the saponin. However, despite its bitter taste, it is also consumed raw, but only in Spain $[4,68]$. The plant was probably used as food already in the times of Pedanius Dioscorides, physician, pharmacologist, and botanist (40-90 AD). According to many scholars Dioscorides mentiones this plant in his famous five-volume encyclopedia "De Materia Medica" [49] (though not everyone agrees, see [69]). This would show that some food habits have remained the same from antiquity. The plant formerly belonged to the genus Dioscorea, dedicated to Dioscorides. Similarly to Tamus communis, Solanum nigrum and Arum maculatum are also toxic. All the three plants are consumed after boiling. That way the bitter taste in the leaves is removed. Among the three, S. nigrum has the most toxic content. The greatest toxicity was detected in the unripe green berries. This species is important especially for Izmir in the study area. Among the locals, it is known with its Greek name "istifno". One of the most common salads made by Cretan immigrants is prepared with this plant. The salad is prepared by boiling fresh shoots and leaves and then by adding fresh courgette, olive oil, and garlic. The use of the plant declines towards the inner parts of the Aegean region, the reason being is that the Cretan immigrants did not settled there. Interestingly, in Cyprus, only the fruits of the plant are consumed and there is no record of consumption of the green parts [59]. The usage of $S$. nigrum's fruits is common in many parts of the world. There are records of similar types of consumption for this study area [25,27]. Redžić [34] and Hadjichambis et al. [2] reported that only fresh shoots of the plant are consumed in Bosnia and Herzegovina, and Greece.

Another typical Crete food, served even in choice restaurants, is prepared with Scolymus hispanicus (the bark of the root and young basal leaf stalks of the plant with lamb). Theophrastus, known as the father of botany (371-287 BC), and Pliny the Elder (23-79 AD) mention the use of this plant as food in their works [49]. The consumption of blessed thistle, which is a Mediterranean element, is not very common especially around Izmir and outside of the places where the Cretan immigrants reside. It is a commonly consumed plant in the Mediterranean countries. In Cyprus, fresh stem and leaves are consumed raw, as well as fried or fried with eggs, after boiling [59]. In Spain, the inner parts of the prickly basal leaves are boiled and then usually lightly fried with a bit of garlic, cured ham, and scrambled eggs [70]. Neither this type of consumption nor the preparation with lamb is reported for the study area.

Daucus carota is a commonly consumed plant. Its roots are commonly used in salads and other foods. In various parts of the area, the leaves and roots of the wild form are used in the preparation of food. Shoots and leaves are consumed in the fall and winter months, while the roots are collected and consumed in the spring. Redžić [71] reported that, apart from the roots and leaves, its seeds are also used as food. Additionally, in some parts of Turkey, especially in the Mersin area, their roots are used in preparation of a sweet called "cezerye" and are widely consumed in all of Turkey.

An endemic plant, Papaver guerlekense, a species similar to $P$. rhoeas, is consumed mixed in green salads, used as pastry stuffing, as a main dish, roasted, in a pie, salad, and soup [25].

Pistacia terebinthus is not a common plant in the study area. It is generally collected from nature and its fresh shoots consumed raw. It is sold in the markets in small amounts. Due to its resin content, it is added to pickles for taste and also cooked with onion and egg. It is only in Cyprus that the plant is used in a similar way [59]. Although there are no literature data on the use of its seeds, a type of coffee is made of the, called "Kenger coffee", which is consumed widely instead of normal coffee in the Eastern Anatolian region (Y. D., unpublished data).

In this study, the Malvaceae family is represented by $L a$ vatera cretica and Malva sylvestris. The former is not commonly consumed [25]. It is usually fried with other herbs and added to pastry. However, the other member of the family, M. sylvestris, is one of the most widely consumed plants in the study area, as well as in other parts of Turkey and all of the Mediterranean Basin. The plant is cooked with minced meat or olive oil, prepared as a soup, put in pastry, or fried with other herbs. In the Aegean part of Turkey it is usually eaten in pastry. Apart from this type of use, common mallow is consumed raw in salads in Northern Italy [66] and Lebanon [72]. This type of use is not encountered anywhere else.

In addition to $M$. sylvestris, which is widely distributed and commonly consumed in the study area, various Malva species such as Malva moschata L., Malva cretica Cav., Malva nicaeensis All., and Malva parviflora L. can be found, although not so commonly. Although these plants can also be consumed similar to $M$. sylvestris, there are no reports of their use. In other areas, $M$. neglecta Wallr. is consumed like M. sylvestris [32,33,36,39,41,73-77].

Plantago lanceolata is one of the plants that is consumed as stuffed, in a pie, and as a salad in the study area, but in other parts of Turkey its fresh leaves are consumed raw. Only Menendez-Baceta et al. [67] reports its fresh leaves being consumed raw in Spain. The closest to this type of use in this area is to chop it up and add to salads. Pieroni $[53,54]$ reports its use as soup and Redžić [34] reports it as cooked vegetables.

Chrysanthemum coronarium (Asteraceae) is one of the rare plants whose leaves are consumed only raw [25]. Similar usage has only been reported for Palestine [50], whereas in Spain it is cooked [4]. There are no other reports for its use. However, consumption of $C$. segetum in the same manner as C. coronarium has been reported by Ertug [25] for Bodrum, which is included in the study area. Rumex acetosella is one of the plants that is consumed raw in the study area. It is eaten 
directly from the field and, in addition to its many other uses. Its green leaves are consumed widely in rural areas due to their sour taste. Plants that are sold in the markets are mostly consumed as a salad [27]. It is commonly consumed in Asian Minor and the whole of Europe.

Purslane (Portulaca oleracea) is a plant that is widely distributed and consumed as food from Central Asia to Central America, from Myanmar to Brazil and from the U. K. to Yemen [49]. It is a commonly consumed plant in the study area and in the whole Mediterranean Basin. Its aboveground parts are added to green salads [27], especially its fresh leaves which are mixed with yogurt and consumed as a salad widely in the study area. They are also commonly cooked. Both the wild and cultural forms exist and the wild forms are preferred in the rural areas, whereas the cultivated varieties are preferred in the urban areas. Purslane, a plant recommended for medicinal use by Dioscorides, has been used as a medicinal food all over the world since antiquity $[49,56]$.

The leaves of Sonchus oleraceus, used in the study area and mentioned already by Dioscorides as food, are consumed as a salad and soup in many parts of the world [49]. In addition to this type of use, it is commonly consumed as a pastry and main dish, as well as boiled and prepared as a salad.

Salicornia europaea (glasswort), which is only consumed along the shores in the Western Anatolia, is a succulent and halophyte plant that grows in salt marshes and seashores. It is commonly consumed but only in areas close to the coast as a salad after boiling. Garlic and especially olive oil are added. It is also eaten in other parts of the Mediterranean [34].

One of the most interesting plants used in the study area is Echinophora tenuifolia subsp. sibthorpiana. It is a very well known and commonly used plant everywhere in Turkey. It is known as "tarhana herb" and is consumed as an addition to the tarhana soup, a soup unique to Anatolia. This taxon is added to tarhana when fresh to give a pleasant aroma and used as an aromatic food preserver in order to prevent pickles from frothing $[25,27,29,78,79]$. No other use of this plant has been reported outside of Anatolia.

In Western Anatolia, the most commonly eaten wild edible greens are Asparagus acutifolius, Beta spp., Cichorium intybus, Foeniculum vulgare, Malva sylvestris, Papaver rhoeas, Portulaca oleracea, Silene vulgaris, Taraxacum spp., and Urtica dioica. These taxa are also widely consumed in other parts of the Mediterranean Basin. Some species, such as Tamus communis, are very commonly consumed in the study area according to the author's unpublished observations, although this is not supported by earlier publications. An ethnobotanical research was carried out by Hadjichambis et al. [2] between 2003-2006 in seven countries from the Eastern Mediterranean (Cyprus, and Greece), the Western Mediterranean (Italy, and Spain), the Adriatic/Balkan Mediterranean (Albania) and the North-African Mediterranean (Egypt, and Morocco). It was a European Union-funded RUBIA Project and wild and semidomesticated food plant consumption was investigated in these countries. As a result of the survey, 294 wild food plant taxa were documented. Asteraceae was the most represented family with 63 taxa. Of the identified plants $21 \%$ belonged to this family compared to $19 \%$ in this study. Similar results were obtained in another study carried out in a part of the study area [30]. The aforementioned wild edible plants are consumed as food in various ways; however, they include some invasive weeds and species under agricultural pest management. In many parts of Turkey, especially in Western Anatolia, some species such as Anagalis arvensis, Cichorium intybus, Fumaria officinalis, Lactuca serriola, Lamium amplexicaule, Lamium moschatum, Malva sylvestris, Papaver rhoeas, Raphanus raphanistrum, Sinapis arvensis, Sisymbrium officinale, Stellaria media, and Tragopogon latifolius are considered as invasive field pests and are controlled with agricultural chemicals. They cause a loss of yield in crops, especially in grains, and therefore various herbicides are applied, which decreases the availability of wild greens.

\section{Conclusion}

In total, 111 taxa that were identified as wild edible greens in the study area belong to 26 different families. Asteraceae is the most commonly consumed family and the results of this study show parallels with other Mediterranean areas.

The majority of the plants identified are species widely distributed in the Mediterranean Basin, due to the fact that the Aegean Region has a Mediterranean climate. In addition, the eastern borders of the region are adjacent to the Irano-Turanian Phytogeographical Region and therefore it contains species unique to that region. As a consequence, there exist species that are not consumed in other Mediterranean countries.

The fact that the majority of the identified plants in the area are consumed as a salad show the local diet has strong Mediterranean features. As a result, very promisingly, there is a renewed or increasing interest in consuming wild food plants as a part of the diet.

\section{Acknowledgements}

The author express his gratitude to Mesut Koyuncu (Tokat University, Tokat), Dr. Ilker Ugulu (Balikesir University, Balikesir), Dr. Anely Nedelcheva (Sofia University, Sofia), Robert J. Kelley (Ege University, Izmir), and Dr. Munir Ozturk (Ege University, Izmir) for their help, constructive comments, and support in the preparation of this manuscript. The author wishes to thank especially those who were interviewed for the key information used in this paper, for their time, and willingness to share their knowledge and experience.

\section{References}

1. Hu FB. The Mediterranean diet and mortality - olive oil and beyond. N Engl J Med. 2003;348(26):2595-2596. http://dx.doi.org/10.1056/ NEJMp030069

2. Hadjichambis ACH, Paraskeva-Hadjichambi D, Della A, Giusti EM, De Pasquale C, Lenzarini C, et al. Wild and semi-domesticated food plant consumption in seven circum-Mediterranean areas. Int J Food Sci Nutr. 2008;59(5):383-414. http://dx.doi.org/10.1080/09637480701566495

3. Petrillo PL. Biocultural diversity and the Mediterranean diet. In: Burlingame B, Dernini D, editors. Sustainable diets and biodiversity directions and solutions for policy, research and action. Rome: FAO; 2012. p. 224-229.

4. Tardío J, Pardo-De-Santayana M, Boyd R. Ethnobotanical review of wild edible plants in Spain. Bot J Linn Soc. 2006;152(1):27-71. http://dx.doi. org/10.1111/j.1095-8339.2006.00549.x

5. Turner NJ, Łuczaj ŁJ, Migliorini P, Pieroni A, Dreon AL, Sacchetti LE, et al. Edible and tended wild plants, traditional ecological knowledge and 
agroecology. Crit Rev Plant Sci. 2011;30(1-2):198-225. http://dx.doi.org /10.1080/07352689.2011.554492

6. Pérez-López FR, Chedraui P, Haya J, Cuadros JL. Effects of the Mediterranean diet on longevity and age-related morbid conditions. Maturitas. 2009;64(2):67-79. http://dx.doi.org/10.1016/j.maturitas.2009.07.013

7. Iannetta M, Colucci F, Presenti O, Vitali F. Food and energy: a sustainable approach. In: Burlingame B, Dernini D, editors. Sustainable diets and biodiversity directions and solutions for policy, research and action. Rome: FAO; 2012. p. 274-279.

8. Dogan Y, Nedelcheva AM, Obratov-Petkovic D, Padure IM. Plants used in traditional handicrafts in several Balkan countries. Indian J Tradit Know. 2008;7:157-161.

9. Ugulu I, Baslar S, Yorek N, Dogan Y. The investigation and quantitative ethnobotanical evaluation of medicinal plants used around Izmir province, Turkey. J Med Plant Res. 2009;3(5):345-367.

10. Wetherilt $\mathrm{H}$. Evaluation of Urtica species as potential sources of important nutrients. Dev Food Sci. 1992;29:15-26.

11. Pieroni A, Nebel S, Santoro RF, Heinrich M. Food for two seasons: culinary uses of non-cultivated local vegetables and mushrooms in a south Italian village. Int J Food Sci Nutr. 2005;56(4):245-272. http://dx.doi. org/10.1080/09637480500146564

12. Dogan Y, Baslar S, Mert HH, Ay G. Plants used as natural dye sources in Turkey. Econ Bot. 2003;57(4):442-453. http://dx.doi. org/10.1663/0013-0001(2003)057[0442:PUANDS]2.0.CO;2

13. Nedelcheva AM, Dogan Y, Guarrera P. Plants traditionally used to make brooms in several European countries. J Ethnobiol Ethnomed. 2007;3(1):20. http://dx.doi.org/10.1186/1746-4269-3-20

14. Dogan Y, Nedelcheva AM, Baslar S. Plant patterns of silk based needlework, a traditional handcraft in Turkey. Indian J Tradit Know. 20120;9(4):640-643.

15. Ugulu I, Baslar S. The determination and fidelity level of medicinal plants used to make traditional Turkish salves. J Altern Complement Med. 2010;16(3):313-322. http://dx.doi.org/10.1089/acm.2009.0040

16. Nedelcheva AM, Dogan Y, Obratov-Petkovic D, Padure IM. The traditional use of plants for handicrafts in southeastern Europe. Hum Ecol. 2011;39(6):813-828. http://dx.doi.org/10.1007/s10745-011-9432-9

17. Ugulu I. Fidelity level and knowledge of medicinal plants used to make therapeutic Turkish baths. Ethno Med. 2012;6(1):1-9.

18. Kocman A. Ege ovalarinin iklimi. Izmir: Ege Universitesi Edebiyat Fakultesi; 1993.

19. Ugulu I, Dogan Y, Kesercioglu T. The vascular plants of Buca Faculty of Education Campus (Izmir): contribution to educational practices. Eurasia J Biosci. 2012;6:11-23. http://dx.doi.org/10.5053/ejobios.2012.6.0.2

20. Yener H. Determination of horizontal and vertical distribution of tree species in Turkey via Shuttle Radar Topography Mission (SRTM) satellite data and geographic information system: the case of Crimean pine (Pinus nigra). Afr J Biotechnol. 2012;11(7):1659-1673. http://dx.doi.org/10.5897/ AJB11.3199

21. Markgraf F. Genetische Beziehungen der Mittelmeerflora. Ber Dtsch Bot Ges. 1934;52:68-79.

22. Padilla M, Capone R, Palma G. Sustainability of the food chain from field to plate: the case of the Mediterranean diet. In: Burlingame B, Dernini D, editors. Sustainable diets and biodiversity directions and solutions for policy, research and action. Rome: FAO; 2012. p. 230-241.

23. Zohary M. Geobotanical foundations of the Middle East. Stuttgart: Gustav Fischer Verlag; 1973.

24. Ozturk M, Secmen O, Kondo K. Vegetation in Aegean region of Turkey. Mem Fac Integ Arts-Sci Hiroshima. 1983;8:53-62.

25. Ertug F. Wild edible plants of the Bodrum area (Mugla, Turkey). Turk J Bot. 2004;28:161-174.

26. Kaya I, Incekara N, Nemli Y. Ege Bölgesi’nde Sebze Olarak Tüketilen Yabani Kuskonmaz, Sirken, Yabani Hindiba, Rezene, Gelincik, Coban Degnegi ve Ebegümecinin Bazı Kimyasal Analizleri. Ingredients of some weeds consumed as food in Aegean region. Tarım Bilimleri Dergisi. 2004;14(1):1-6.

27. Dogan Y, Baslar S, Ay G, Mert HH. The use of wild edible plants in western and central Anatolia (Turkey). Econ Bot. 2004;58(4):684-690. http://dx.doi.org/10.1663/0013-0001(2004)058[0684:TUOWEP]2.0.CO;2

28. Kargioglu M, Cenkci S, Serteser A, Evliyaoglu N, Konuk M, Kok MS, et al. An ethnobotanical survey of inner-west Anatolia, Turkey. Hum Ecol. 2008;36(5):763-777. http://dx.doi.org/10.1007/s10745-008-9198-x

29. Kargioglu M, Cenkci S, Serteser A, Konuk M, Vural G. Traditional uses of wild plants in the middle Aegean region of Turkey. Hum Ecol. 2010;38(3):429-450. http://dx.doi.org/10.1007/s10745-010-9318-2

30. Ahiskali M, Ari C, Selvi S. Edible wild plants and their consumption during winter in a rural village on Kazdagi (Mount Ida). Bocconea. 2012;24:195-198.

31. Davis PH. Flora of Turkey: and the East Aegean Islands. Edinburgh: Edinburgh University Press; 1965-1988. (vol 1-10).

32. Ozbucak TB, Kutbay HG, Akcin OE. The contribution of wild edible plants to human nutrition in the Black Sea region of Turkey. Ethnobotanical Leaflets. 2006;10:98-103.

33. Cakilcioglu U, Khatun S. Nitrate, moisture and ash contents of edible wild plants. J Cell Plant Sci. 2011;2(1):1-5.

34. Redzic SJ. Wild edible plants and their traditional use in the human nutrition in Bosnia-Herzegovina. Ecol Food Nutr. 2006;45(3):189-232. http:// dx.doi.org/10.1080/03670240600648963

35. Kizil S. Determination of essential oil variations of Thymbra spicata var. spicata L. naturally growing in the wild flora of East Mediterranean and Southeastern Anatolia regions of Turkey. Ind Crops Prod. 2010;32(3):593600. http://dx.doi.org/10.1016/j.indcrop.2010.07.008

36. Alan R, Padem H. A research on the composition of Rheum ribes L., Tragopogon albinervis L., Polygonum cognatum Meissn., Chenopodium album L. and Malva neglecta Wallr. used in human nutrition in Erzurum. Gida Dergisi. 1989;14(5):281-287.

37. Ertug F. An ethnobotanical study in Central Anatolia (Turkey). Econ Bot. 2000;54(2):155-182. http://dx.doi.org/10.1007/BF02907820

38. Tosun I, Karadeniz B, Yuksel S. The nitrate content of some edible wild plants consumed in Samsun region. Ekoloji. 2003;12(47):32-34.

39. Turan M, Kordali S, Zengin H, Dursun A, Sezen Y. Macro and micro mineral content of some wild edible leaves consumed in eastern Anatolia. Acta Agric Scand B. 2003;53(3):129-137. http://dx.doi. org/10.1080/090647103100095

40. Ufuk O, Yusuf K, Maksut C. Ethnobotancal studies in the villages of the district of Ilica (Province Erzurum), Turkey. Econ Bot. 2004;58(4):691696. http://dx.doi.org/10.1663/0013-0001(2004)058[0691:ESITVO]2.0 . $\mathrm{CO} ; 2$

41. Yücel E, Güney F, Yücel Şengün I. The wild plants consumed as a food in Mihaliccik district (Eskisehir/Turkey) and consumption forms of these plants. Bio Di Con. 2010;3(3):158-175.

42. Abak K, Duzenli A. Use of some wild plants as vegetables in Turkey. Acta Hortic. 1989;242:107-114.

43. Hadad Chi GHR, Moradi Z. The amounts and distribution of diosgenin and saponin and their carbohydrate moiety of Tamus communis L. J Agric Sci Natur Resour. 2005;12(2):55-66.

44. Morales P, Carvalho AM, Sánchez-Mata MC, Cámara M, Molina M, Ferreira ICFR. Tocopherol composition and antioxidant activity of Spanish wild vegetables. Genet Resour Crop Evol. 2011;59(5):851-863. http:// dx.doi.org/10.1007/s10722-011-9726-1

45. Pieroni A, Nebel S, Quave C, Münz H, Heinrich M. Ethnopharmacology of liakra: traditional weedy vegetables of the Arbëreshë of the Vulture area in southern Italy. J Ethnopharmacol. 2002;81(2):165-185. http://dx.doi. org/10.1016/S0378-8741(02)00052-1

46. Morales P, Ferreira I, Carvalho A, Sanchez-Mata M, Camara M, Tardio J. Fatty acids profiles of some Spanish wild vegetables. Food Sci Tech Int. 2012;18(3):281-290. http://dx.doi.org/10.1177/1082013211427798 
47. Guarrera PM. Food medicine and minor nourishment in the folk traditions of Central Italy (Marche, Abruzzo and Latium). Fitoterapia. 2003;74(6):515-544. http://dx.doi.org/10.1016/S0367-326X(03)00122-9

48. Tardío J, Pascual H, Morales R. Wild food plants traditionally used in the province of Madrid, Central Spain. Econ Bot. 2005;59(2):122-136. http://dx.doi.org/10.1663/0013-0001(2005)059[0122:WFPTUI]2.0.CO;2

49. Lentini F, Venza F. Wild food plants of popular use in Sicily. J Ethnobiol Ethnomed. 2007;3(1):15. http://dx.doi.org/10.1186/1746-4269-3-15

50. Ali-Shtayeh MS, Jamous RM, Al-Shafie JH, Elgharabah WA, Kherfan FA, Qarariah KH, et al. Traditional knowledge of wild edible plants used in Palestine (Northern West Bank): a comparative study. J Ethnobiol Ethnomed. 2008;4(1):13. http://dx.doi.org/10.1186/1746-4269-4-13

51. Martins D, Barros L, Carvalho AM, Ferreira ICFR. Nutritional and in vitro antioxidant properties of edible wild greens in Iberian Peninsula traditional diet. Food Chem. 2011;125(2):488-494. http://dx.doi.org/10.1016/j. foodchem.2010.09.038

52. Di Tizio A, Łuczaj ŁJ, Quave CL, Redžić S, Pieroni A. Traditional food and herbal uses of wild plants in the ancient South-Slavic diaspora of Mundimitar/Montemitro (Southern Italy). J Ethnobiol Ethnomed. 2012;8(1):21. http://dx.doi.org/10.1186/1746-4269-8-21

53. Pieroni A. Gathered wild food plants in the upper valley of the Serchio River (Garfagnana), Central Italy. Econ Bot. 1999;53(3):327-341. http:// dx.doi.org/10.1007/BF02866645

54. Pieroni A. Medicinal plants and food medicines in the folk traditions of the upper Lucca Province, Italy. J Ethnopharmacol. 2000;70(3):235-273. http://dx.doi.org/10.1016/S0378-8741(99)00207-X

55. Bonet MA, Vallès J. Use of non-crop food vascular plants in Montseny biosphere reserve (Catalonia, Iberian Peninsula). Int J Food Sci Nutr. 2002;53(3):225-248. http://dx.doi.org/10.1080/09637480220132841

56. Rivera D, Obon C, Inocencio C, Heinrich M, Verde A, Fajardo J, et al. The ethnobotanical study of local Mediterranean food plants as medicinal resources in Southern Spain. J Physiol Pharmacol. 2005;56 Suppl 1:97-114.

57. Salvatore S, Pellegrini N, Brenna OV, Del Rio D, Frasca G, Brighenti F, et al. Antioxidant characterization of some Sicilian edible wild greens. J Agric Food Chem. 2005;53(24):9465-9471. http://dx.doi.org/10.1021/ jf051806r

58. Scherrer AM, Motti R, Weckerle CS. Traditional plant use in the areas of Monte Vesole and Ascea, Cilento National Park (Campania, Southern Italy). J Ethnopharmacol. 2005;97(1):129-143. http://dx.doi.org/10.1016/j. jep.2004.11.002

59. Della A, Paraskeva-Hadjichambi D, Hadjichambis AC. An ethnobotanical survey of wild edible plants of Paphos and Larnaca countryside of Cyprus. J Ethnobiol Ethnomed. 2006;2(1):34. http://dx.doi. org/10.1186/1746-4269-2-34

60. Nebel S, Pieroni A, Heinrich M. Ta chòrta: wild edible greens used in the Graecanic area in Calabria, Southern Italy. Appetite. 2006;47(3):333-342. http://dx.doi.org/10.1016/j.appet.2006.05.010

61. Ghirardini M, Carli M, Del Vecchio N, Rovati A, Cova O, Valigi F, et al. The importance of a taste. A comparative study on wild food plant consumption in twenty-one local communities in Italy. J Ethnobiol Ethnomed. 2007;3(1):22. http://dx.doi.org/10.1186/1746-4269-3-22

62. Pardo-de-Santayana M, Tardío J, Blanco E, Carvalho A, Lastra J, San Miguel E, et al. Traditional knowledge of wild edible plants used in the northwest of the Iberian Peninsula (Spain and Portugal): a comparative study. J Ethnobiol Ethnomed. 2007;3(1):27. http://dx.doi. org/10.1186/1746-4269-3-27

63. Rivera D, Obón C, Inocencio C, Heinrich M, Verde A, Fajardo J, et al. Gathered food plants in the mountains of Castilla-La Mancha (Spain): ethnobotany and multivariate analysis. Econ Bot. 2007;61(3):269-289. http://dx.doi.org/10.1663/0013-0001(2007)61[269:GFPITM]2.0.CO;2

64. Aberoumand A, Deokule SS. Comparison of phenolic compounds of some edible plants of Iran and India. Pakistan J Nutr. 2008;7(4):582-585.

65. Nebel S, Heinrich M. Ta chòrta: a comparative ethnobotanical-linguistic study of wild food plants in a Graecanic area in Calabria, Southern Italy. Econ Bot. 2009;63(1):78-92. http://dx.doi.org/10.1007/s12231-008-9069-9

66. Mattalia G, Quave CL, Pieroni A. Traditional uses of wild food and medicinal plants among Brigasc, Kyé, and Provençal communities on the Western Italian Alps. Genet Resour Crop Evol. 2012. http://dx.doi. org/10.1007/s10722-012-9859-x

67. Menendez-Baceta G, Aceituno-Mata L, Tardío J, Reyes-García V, Pardode-Santayana M. Wild edible plants traditionally gathered in Gorbeialdea (Biscay, Basque Country). Genet Resour Crop Evol. 2012;59(7):13291347. http://dx.doi.org/10.1007/s10722-011-9760-z

68. Sánchez-Mata MC, Cabrera Loera RD, Morales P, Fernández-Ruiz V, Cámara M, Díez Marqués $\mathrm{C}$, et al. Wild vegetables of the Mediterranean area as valuable sources of bioactive compounds. Genet Resour Crop Evol. 2012;59(3):431-443. http://dx.doi.org/10.1007/s10722-011-9693-6

69. Renner SS, Scarborough J, Schaefer H, Paris HS, Janick J. Dioscorides's Bruonia melaina is Bryonia alba, not Tamus communis, and an illustration labeled Bruonia melaina in the Codex Vindobonensis is Humulus lupulus not Bryonia dioica. In: Pitrat M, editor. Cucurbitaceae 2008: proceedings of the IXth EUCARPIA meeting on genetics and breeding of Cucurbitaceae. Avignon: INRA; 2008. p. 273-280.

70. Polo S, Tardío J, Vélez-del-Burgo A, Molina M, Pardo-de-Santayana M. Knowledge, use and ecology of golden thistle (Scolymus hispanicus L.) in Central Spain. J Ethnobiol Ethnomed. 2009;5(1):42. http://dx.doi. org/10.1186/1746-4269-5-42

71. Redzić S. Use of wild and semi-wild edible plants in nutrition and survival of people in 1430 days of siege of Sarajevo during the war in Bosnia and Herzegovina (1992-1995). Coll Antropol. 2010;34(2):551-570.

72. Batal M, Hunter E. Traditional Lebanese recipes based on wild plants: an answer to diet simplification? Food Nutr Bull. 2007;28(2 suppl):303-311.

73. Gurses O, Artik N. A research on the composition of Beta vulgaris var. cicla L., Malva neglecta Wallr., Portulaca oleracea L. and Spinacia oleracea L. Gida Dergisi. 1984;9(2):83-87.

74. Alan R, Padem H. A research on the composition of Rumex crispus L., Atriplex petula L., Polygonum aviculare L., Prangos uechtritzii Boiss. and Tragopogon reticulatus Boiss., used in human nutrition in Erzurum. Turk J Agric For. 1990;14:48-57.

75. Ayan I, Acar Z, Mut H, Basaran U, Asci O. Morphological, chemical and nutritional properties of forage plants in a natural rangeland in Turkey. Bangladesh J Bot. 2006;35(2):133-142.

76. Akcin OE, Ozbucak TB. Morphological, anatomical and ecological studies on medicinal and edible plant Malva neglecta Wallr. (Malvaceae). Pak J Biol Sci. 2006;9(14):2716-2719. http://dx.doi.org/10.3923/ pjbs.2006.2716.2719

77. Sekeroglu N, Ozkutlu F, Deveci M, Dede O, Yilmaz N. Evaluation of some wild plants aspect of their nutritional values used as vegetable in eastern Black Sea region of Turkey. Asian J Plant Sci. 2006;5(2):185-189. http:// dx.doi.org/10.3923/ajps.2006.185.189

78. Sivga HO, Secmen O. Ethnobotanic survey of Isikli (Carpin), Dagdancik and Tokdemir in Gaziantep, Turkey. IUFS J Biol. 2009;68(1):19-26.

79. Chalchat JC, Ozcan MM, Figueredo G, Chalard P. The effect of harvest years on chemical composition of essential oil of pickling herb (Echinophora tenuifolia subsp. sibthorpiana) leaves used as medicinal plant. Acta Bot Hung. 2011;53(1):73-77. http://dx.doi.org/10.1556/ ABot.53.2011.1-2.6

80. Leonti M, Nebel S, Rivera D, Heinrich M. Wild gathered food plants in the European Mediterranean: a comparative analysis. Econ Bot. 2006;60(2):130-142. http://dx.doi. org/10.1663/0013-0001(2006)60[130:WGFPIT]2.0.CO;2

81. Simopoulos AP. Omega-3 fatty acids and antioxidants in edible wild plants. Biol Res. 2004;37(2):263-277. http://dx.doi.org/10.4067/ S0716-97602004000200013

82. Uysal I, Onan S, Karabacak E, Celik S. Ethnobotanical aspects of Kapidag Peninsula (Turkey). Bio Di Con. 2010;3(3):15-22. 
83. Kocyigit M, Ozhatay N. The wild edible and miscellaneous useful plants in Yalova province (northwest Turkey). J Fac Pharm Istanbul. 2009;40:19-29.

84. Lemordant D. Plantes utiles et toxiques de Tunisie. Fitoterapia. 1977;48:191-214.

85. Vanzani P, Rossetto M, De Marco V, Sacchetti L, Paoletti MG, Rigo A. Wild mediterranean plants as traditional food: a valuable source of antioxidants. J Food Sci. 2011;76(1):C46-C51. http://dx.doi. org/10.1111/j.1750-3841.2010.01949.x

86. Yildirim E, Dursun A, Turan M. Determination of the nutrition contents of the wild plants used as vegetables in Upper Coruh Valley. Turk J Bot. 2001;25:367-371.

87. Rigat M, Bonet MA, Garcia S, Garnatje T, Vallès J. Ethnobotany of food plants in the high river Ter Valley (Pyrenees, Catalonia, Iberian Peninsula): non-crop food vascular plants and crop food plants with medicinal properties. Ecol Food Nutr. 2009;48(4):303-326. http://dx.doi. org/10.1080/03670240903022320

88. Dogru Koca A, Yildirimli s. Ethnobotanical properties of Akçakoca District in Düzce (Turkey). Hacettepe J Biol Chem. 2010;38(1):63-69.

89. Akgunlu SB. Mineral content and microbiological analysis of some wild edible vegetables consumed in Kilis and Gaziantep provinces [Master thesis]. Kilis: Kilis 7 Aralık University; 2012.

90. Pieroni A. Evaluation of the cultural significance of wild food botanicals traditionally consumed in Northwestren Tuscany, Italy. J Ethnobiol. 2001;21:89-104.

91. Pieroni A, Giusti M. Alpine ethnobotany in Italy: traditional knowledge of gastronomic and medicinal plants among the Occitans of the upper Varaita valley, Piedmont. J Ethnobiol Ethnomed. 2009;5(1):32. http:// dx.doi.org/10.1186/1746-4269-5-32

92. Motti R, Antignani V, Idolo M. Traditional plant use in the Phlegraean
Fields Regional Park (Campania, Southern Italy). Hum Ecol. 2009;37(6):775-782. http://dx.doi.org/10.1007/s10745-009-9254-1

93. Shafaghat A. Volatile oil constituents and antibacterial activity of different parts of Falcaria vulgaris Bernh. growing wild in two localities from Iran. Nat Prod Res. 2011;25(4):368-373. http://dx.doi. org/10.1080/14786411003774312

94. Lev-Yadun S, Abbo S. Traditional use of A'kub (Gundelia tournefortii, Asteraceae), in Israel and the Palestinian Authority area. Econ Bot. 1999;53(2):217-219. http://dx.doi.org/10.1007/BF02866501

95. Halabi S, Battah AA, Aburjai T, Hudaib M. Phytochemical and antiplatelet investigation of Gundelia tournifortii. Pharm Biol. 2005;43(6):496-500. http://dx.doi.org/10.1080/13880200500220268

96. Coruh N, Sagdicoglu Celep AG, Ozgokce F, Iscan M. Antioxidant capacities of Gundelia tournefortii L. extracts and inhibition on glutathione-Stransferase activity. Food Chem. 2007;100(3):1249-1253. http://dx.doi. org/10.1016/j.foodchem.2005.12.008

97. Tardio J, Pardo-de-Santayana M. Cultural importance indices: a comparative analysis based on the useful wild plants of Southern Cantabria (Northern Spain). Econ Bot. 2008;62(1):24-39. http://dx.doi.org/10.1007/ s12231-007-9004-5

98. Razavi SM, Zarrini G, Molavi G, Ghader G. Bioactivity of Malva sylvestris L., a medicinal plant from Iran. Iran J Basic Med Sci. 2011;14(6):574-579.

99. Pardo-De-Santayana M, Tardio J, Morales R. The gathering and consumption of wild edible plants in the Campoo (Cantabria, Spain). Int J Food Sci Nutr. 2005;56(7):529-542. http://dx.doi.org/10.1080/09637480500490731

100. Gencay A. Ethnobotanical aspects of Cizre (Sirnak) [Master thesis]. Van: Yuzuncu Yil Universitesi; 2007.

101. Ayan AK, Caliskan O, Cirak C. Economical importance of stinging nettle (Urtica spp.) and its cultivation. J Fac Agric OMU. 2006;21(3):357-363. 